\title{
PATTERN OF MENSTRUAL CYCLE AFTER KIDNEY TRANSPLANT IN REPRODUCTIVE WOMEN
}

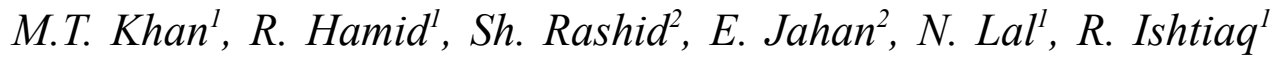 \\ ' Renal Transplant Unit, National Institute of Solid Organ and Tissue Transplantation, Dow University \\ Hospital, Karachi, Pakistan \\ ${ }^{2}$ Karachi Medical and Dental College, Karachi, Pakistan
}

\begin{abstract}
Background. In reproductive women, transplant disturbs the menstrual cycle pattern. The two major conditions usually encountered are amenorrhea and menorrhagia. The objective of the study was to assess the pattern of menstrual cycle after kidney transplant in reproductive women. Materials and methods. This cross-sectional study was carried out in a public sector hospital of Karachi, Pakistan. A total 69 patients of reproductive age were included who underwent living kidney donor transplant for more than a year ago. Women having genital tract infection, using hormonal treatment, organic cause of genital tract, clotting disorder and severe cardiac and/ or peripheral vascular disease were excluded. Frequency and percentages were calculated for demographic characteristics. Correlation and association analysis was calculated for type of menstruation with menstrual cycle pattern. A P-value less than 0.05 was considered statistically significant. Results. Majority of female included in the study aged between $35-39$ years $(36,52.2 \%)$. The most frequent menstrual disturbance observed was heavy menstrual bleeding $(22,31.9 \%)$ and amenorrhea $(21,30.4 \%)$. Only $2.9 \%$ cases showed normal menstrual pattern. The cross tabulation indicated that $26.1 \%$ patients had amenorrhea, $24.6 \%$ had oligomenorrhea and $31.9 \%$ had menorrhagia. The Durbin-Watson value of 0.656 indicated a strong positive relationship between menstruation cycle pattern (dependent variable) and type of menstruation, marital status, donor's age, children and living location of the patients (independent variables). Conclusion. From the result of the present study, it is concluded that the reproductive age women have shown a disturbed pattern of menstrual cycle after kidney transplant. The major observation was that such patients reported amenorrhea, menorrhagia, oligomenorrhea and hypomenorrhea.
\end{abstract}

Keywords: Reproductive Women, Amenorrhea, Oligomenorrhea, Menorrhagia, Renal Transplant.

\section{ОСОБЕННОСТИ МЕНСТРУААЬНОГО ЦИКАА ПОСАЕ ТРАНСПААНТАЦИИ ПОЧКИ У ЖЕНЩИН PEПРОАУКТИВНОГО ВОЗРАСТА}

\author{
M.T. Хан ${ }^{1}$, Р.Б. Хамид ${ }^{1}$, Ш. Рашид², Э. Джахан ${ }^{2}$, Н. Лал ${ }^{1}$, Р. Иитиак ${ }^{1}$ \\ 'ОтАеление почечной трансплантации, Национальный институт трансплантации солилных органов \\ и тканей, Университетская больница Аау, Карачи, Пакистан \\ ${ }^{2}$ Медицинский и стоматологический комлеАж Карачи, Карачи, Пакистан
}

\begin{abstract}
Актуальность. У женщин репродуктивного возраста трансплантация нарушает характер менструального цикла. Обычно встречаются два основных состояния - аменорея и гиперменорея. Цель исследования оценить характер менструального цикла после трансплантации почки у женщин репродуктивного возраста. Материалы и методы. Настоящее одномоментное исследование проводилось в государственной больнице в г. Карачи, Пакистан. Всего в исследование было включено 69 пациенток репродуктивного возраста, перенесших трансплантацию почки от живого донора более года назад. Исключались женщины с инфекцией половых путей, принимающие гормональные препараты, имеющие органические причины заболевания половых путей, нарушения свертываемости крови и тяжелые заболевания сердца и/или периферических сосудов. Для исследуемых параметров рассчитывали частоту и процентное соотношение. Проводили анализ корреляции и ассоциации типа менструации с длительностью менструального цикла. Значение $\mathrm{p}<0,05$ считалось статистически значимым. Результаты. Возраст большинства женщин, включенных
\end{abstract}

Corresponding author: Muhammad Tassaduq Khan. Renal Transplant Unit, National Institute of Solid Organ and Tissue

Transplantation, Dow University Hospital, Karachi, Pakistan.

Cell: +92 335 2797755. E-mail: muhammad.tassaduq@duhs.edu.pk 
в исследование, составлял 35-39 лет (36; 52,2\%). Наиболее частыми нарушениями менструального цикла были обильные менструальные кровотечения $(22 ; 31,9 \%)$ и аменорея $(21 ; 30,4 \%)$. Менструации были нормальными только в 2,9\% случаев. Кросс-табуляция показала, что у $26,1 \%$ развивалась аменорея, у $24,6 \%-$ олигоменорея и у $31,9 \%$ - гиперменорея. Значение коэффициента Дурбина-Уотсона $(0,656)$ указывает на сильную положительную связь между характером менструального цикла (зависимая переменная) и типом менструации, семейным положением, возрастом донора, наличием детей и местом проживания пациенток (независимые переменные). Выводы. По результатам настоящего исследования можно сделать вывод, что у женщин репродуктивного возраста после трансплантации почки нарушался менструальный цикл. Основное нарушение заключалось в том, что у таких пациенток отмечались аменорея, гиперменорея, олигоменорея и гипоменорея.

Ключевые слова: женщины репродуктивного возраста, аменорея, олигоменорея, гиперменорея, трансплантачия почки.

\section{INTRODUCTION}

Chronic kidney disease (CKD) is a major global health problem in about $11-17 \%$ [1]. Globally, about $37 \%$ of the CKD patients get kidney transplantation [2]. In CKD, other organ functions are also highly affected. In females, irregular pattern of menstruation has been reported in $66 \%$ to $80 \%$ of the women, leading to either amenorrhea, polymenorrhea, oligomenorrhea or heavy menstrual bleeding [3-6]. In the end stage renal disease (ESRD), the pulsatile secretion of gonadotropin releasing hormone $(\mathrm{GnRH})$ is affected, eventually results in loss of release of luteinizing hormone $(\mathrm{LH})$ and causing anovulation [7-9]. After kidney transplant, immunosuppressive therapy resumes ovarian function in approximately $73.9 \%$ in about one year time $[10,11]$. There is little information in the literature about changing menstrual patterns after kidney transplantation. The aim of this study was to observe the post-transplant menstrual pattern in women in our local population.

\section{MATERIALS AND METHODS}

This cross-sectional study was carried out in a public sector hospital of Karachi, Pakistan during January 2018 to April 2021. Ethical considerations were followed according to Helsinki Declaration. Patients were enrolled using convenient sampling after their written informed consent. They were properly briefed about the study and were assured that their identity will remain confidential to all other than the researchers themselves. A total $69 \mathrm{pa}-$ tients of reproductive age were included who underwent living kidney donor transplant for more than a year ago. Women having genital tract infection, using hormonal treatment, organic cause of genital tract, clotting disorder and severe cardiac and/or peripheral vascular disease were excluded. A standardized proforma for data collection was developed. Data including age, marital status, number of children, living location of the patients and types of menstruation and menstruation cycle pattern were recorded via face to face interview by a research personnel. Types of menstruation was set as independent variables, while menstruation cycle pattern was defined as dependent variable. Menstrual pattern were classified into polymenorrhea $<21$ days, normal (22-35 days) and oligomenorrhea $>35$ days. Data was entered and analyzed using Statistical Package for Social Sciences (SPSS) version 20. Frequency and percentages were calculated for demographic characteristics. Correlation and association analysis was calculated for type of menstruation with menstrual cycle pattern. A $P$-value less than 0.05 was considered statistically significant.

\section{RESULT}

The demographic characteristics of study participants are shown in Table 1. Majority of female included in the study aged between $35-39$ years $(36,52.2 \%)$. The menstrual cycle pattern is shown in Table 2 . The most frequent menstrual disturbance observed was heavy menstrual bleeding $(22,31.9 \%)$ and amenorrhea $(21,30.4 \%)$. Only $2.9 \%$ cases showed normal menstrual pattern. The cross tabulation indicated that $26.1 \%$ patients had amenorrhea, $24.6 \%$ had oligomenorrhea and $31.9 \%$ had menorrhagia. The Durbin-Watson value of 0.656 indicated a strong positive relationship between menstruation cycle pattern (dependent variable) and type of menstruation, marital status, donor's age, children and living location of the patients (independent variables).

\section{DISCUSSION}

Kidney transplant is the best kidney replacement treatment for ESRD and poor quality of life. Usually, kidney transplant is recommended when the glomerular filtration rate (GFR) is less than $15 \mathrm{ml} / \mathrm{min} / 1.73 \mathrm{~cm}^{2}$. Furthermore, in other words, the kidney transplant is needed when kidney's functional ability is lost about $90 \%$. At this stage, the body's response to medicines is nearly $10 \%$ along with further emergence of other diseases. The liver and the reproductive organ are significantly damaged by kidney failure due to high imbalance of electrolytes, fluid retention, occasional urinary output and edema. Edema occurs due to high sodium in circulation with high fluid retention, less vessel filtration leading to development of pressure on heart and brain as well [12] 
The peered articles documented that in kidney transplant recipients' anovulation can be completely reversed through a series of medications and the patients can conceive and give birth in a healthy and normal manner. Moreover, start of menstruation cycle is considered as one of the major advantages of kidney transplant women of reproductive age. Patients with stable creatinine level are even more likely to attain normal menstruation cycle within six months [6].

\section{Demographic Characteristics of Study Subjects}

\begin{tabular}{|c|c|c|c|}
\hline S. No & Variables & $\begin{array}{l}\text { Frequency } \\
\text { (n) }\end{array}$ & $\begin{array}{c}\text { Percentage } \\
(\%)\end{array}$ \\
\hline \multirow{6}{*}{1.} & \multicolumn{3}{|l|}{ Age (Years) } \\
\hline & $20-24$ & 01 & 1.4 \\
\hline & $25-29$ & 05 & 7.2 \\
\hline & $30-34$ & 24 & 34.8 \\
\hline & $35-39$ & 36 & 52.2 \\
\hline & 40 years and above & 03 & 4.3 \\
\hline \multirow{4}{*}{2.} & \multicolumn{3}{|l|}{ Marital Status } \\
\hline & Unmarried & 02 & 2.9 \\
\hline & Married & 57 & 82.6 \\
\hline & Separated / Divorced & 10 & 14.5 \\
\hline \multirow{5}{*}{3.} & \multicolumn{3}{|l|}{ Parity } \\
\hline & Nulliparous & 09 & 13.0 \\
\hline & $1-2$ & 39 & 56.5 \\
\hline & $3-4$ & 18 & 26.1 \\
\hline & $>4$ & 03 & 4.3 \\
\hline \multirow{6}{*}{4.} & \multicolumn{3}{|l|}{ Residence } \\
\hline & Karachi & 27 & 39.1 \\
\hline & Sindh & 21 & 30.4 \\
\hline & Punjab & 07 & 10.1 \\
\hline & KPK & 12 & 17.4 \\
\hline & Baluchistan & 02 & 2.9 \\
\hline \multirow{4}{*}{5.} & \multicolumn{3}{|l|}{ Duration of Menses } \\
\hline & $>21$ days & 03 & 4.3 \\
\hline & $21-45$ days & 48 & 69.6 \\
\hline & \begin{tabular}{|l|l|}
$<5$ days \\
\end{tabular} & 18 & 26.1 \\
\hline \multirow{6}{*}{6.} & \multicolumn{3}{|l|}{ Menstrual Pattern } \\
\hline & Normal & 02 & 2.9 \\
\hline & Amenorrhea & 21 & 30.4 \\
\hline & Oligomenorrhea & 17 & 24.6 \\
\hline & Hypomenorrhea & 07 & 10.1 \\
\hline & Menorrhagia & 22 & 31.9 \\
\hline
\end{tabular}

On the other hand, high creatinine level takes time, either a year or two to restore normal ovulation. Furthermore, in women of reproductive age, the kidney disease primarily cause abnormal ovarian function. The level of irregularity of normal hypothalamus pituitary gonadal axis is dependent on the magnitude of kidney disorder [13].

In normal health condition, the LH and follicle stimulating hormone (FSH) are metabolized by liver and kidneys. But, in case of renal disease, primarily at last stage, these hormones get raised in the bloodstream.

Table 1 The kidney transplantation improves metabolism of LH and FSH. Furthermore, at post kidney transplantation, usually Rapamycin inhibitors are given that assist in normalizing these reproductive hormones to restore the ovulation cycle [14].

The most frequent menstrual disturbance observed in present study was oligomenorrhea and amenorrhea. It could be due to hormonal imbalance in pre-kidney transplant phase in reproductive women. This elevated hormone prolactin occurs due to incrimination of urine wastes in blood. The kidney transplantation improves the GFR, restoring prolactin metabolism and safely eliminating the end product through urine. It has also been found that prolactin secretion is highly sensitive and is largely affected by the daily life stresses. Besides, the restoration of prolactin and testosterone level also gets normal in post-transplant phase [15].

Though menstruation is a part of normal reproductive cycle of female, it plays a significant role in women's health and easily disturbed by disease processes. It can affect both physical and psychological health. Menstrual pattern variation is frequently observed among female with CKD and after kidney transplant. The pattern of menstrual periods after kidney transplant is irregular and women experience bleeding mostly after 16 days with more than $20 \mathrm{ml}$ of bleeding. Due to decreased progesterone level with high level of FSH, LH and estrogen, this condition is usually experienced by women mostly after 16 days. Our study results correlates with this finding. The hormonal irregularities shortens the luteal phase. The cycle is continued for more than 7 days. The overall prevalence of menstrual disturbances in reproductive women in CKD is reportedly $64.2 \%$ [16]. In our study, overall menstrual disturbances was found to be $69.6 \%$.

Association between Menstrual Pattern and Type of Menstruation (P-value $<0.0001)$

\begin{tabular}{|l|l|c|c|c|c|c|}
\hline S. No & \multicolumn{1}{|c|}{ Menstrual Pattern } & Amenorrhea & Hypomenorrhea & Normal & Oligomenorrhea & Menorrhagia \\
\hline 1. & Normal $(21-35$ days $)$ & $3(4.3 \%)$ & 0 & 0 & 0 & 0 \\
\hline 2. & Short cycle $(>21$ days $)$ & $18(26.1 \%)$ & $7(10.1 \%)$ & $2(2.9 \%)$ & $17(24.6 \%)$ & $4(5.8 \%)$ \\
\hline 3. & Longer $(<35$ days $)$ & 0 & 0 & 0 & 0 & $18(26.1 \%)$ \\
\hline Total & $21(30.4 \%)$ & $7(10.1 \%)$ & $2(2.9 \%)$ & $17(24.6 \%)$ & $22(31.9 \%)$ \\
\hline
\end{tabular}


Our findings are different from others. One study showed no difference between bleeding pattern before and after transplantation [17]. Another case-control study showed regular menstrual cycle in $72.7 \%$. This result did not correlate with our findings and this might be due to data collection which was done after $1-5$ years posttransplantation. Thus, the duration was long as compared to our study [18].

Usually, after six months of kidney transplantation, the normal ovarian cycle restoration occurs. The hormonal therapy reduces the thickness of endometrium with ameliorating the FSH, LH, estrogen and progesterone. The inhibin hormone causes to stop the cycle with 7 days of bleeding of less than $10 \mathrm{ml}$. Furthermore, it also improves the ovulatory phase that assists in normal formation of endometrium [19]. The cycle is repeated after 24 to 31 days with normal releasing and inhibin pattern. The 5 days of menstruation is with $5 \mathrm{ml}$ to $8 \mathrm{ml}$ blood [20]. The result on cycle length shows $69.6 \%$ of the females reported menstrual cycle shorter than 21 days and $26.1 \%$ had menstrual cycle longer than 35 days. Earlier studies did show variable results regarding cycle length. The result of the present study showed a significant association between menstrual pattern and type of menstruation $(P$-value $<0.0001)$.

The findings of our study showed higher incidence of menstrual pattern disturbance. However, our study findings are limited by studying of only clinical symptoms and their relations. Further exploratory research in this regard is needed.

\section{CONCLUSION}

From the result of the present study, it is concluded that the reproductive age women have shown a disturbed pattern of menstrual cycle after kidney transplant. The major observation was that such patients reported amenorrhea, menorrhagia, oligomenorrhea and hypomenorrhea. Adopting healthy life style is of utmost importance and can significantly reduce the number of affected individuals and burden of this underestimated disease.

We thank to all patients participating in the study, without whom this study would not have been possible.

Авторы заявляют об отсутствии

конфликта интересов.

The authors declare no conflict of interest.

\section{СПИСОК АИТЕРАТУРЫ / REFERENCES}

1. Sarada SG, Ramalakshmi S. Menstrual disorders in chronic kidney disease: causes and management. Int $J$ of Clinic Obstet and Gynaecol. 2020; 4 (2): 353-358.

2. Nastasi AJ, McAdams-DeMarco MA, Schrack J, Ying H, Olorundare I, Warsame $F$ et al. Pre-kidney transplant lower extremity impairment and post-kidney transplant mortality. American Journal of Transplantation. 2018 Jan; 18 (1): 189-196. https://onlinelibrary.wiley.com/ doi/abs/10.1111/ajt.14430.

3. Lin C-T, Liu X-N, Xu H-L, Sui H-Y. Menstrual Disturbances in Premenopausal Women with End-Stage Renal Disease: A Cross-Sectional Study. Med Princ Pract. 2016; 25: 260-265. doi: 10.1159/000444879.

4. Fayed A, Soliman A, Naguib M, Soliman M, Salaheldin M. Ovarian reserve in an Egyptian cohort with end-stage kidney disease on hemodialysis and after successful kidney transplantation: a prospective study. International urology and nephrology. 2019 Apr; 51 (4): 737-743. https://link.springer.com/article/10.1007/ s11255-019-02089-2.

5. Sikora-Grabka E, Adamczak M, Kuczera P, Wiecek A. Serum sex hormones concentrations in young women in the early period after successful kidney transplantation. Endokrynologia Polska. 2018; 69 (2): 150-155. https:// journals.viamedica.pl/endokrynologia_polska/article/ view/51921.

6. Schmidt E, Pachtman SL, Diedrich JT. Contraception in Chronic Kidney Disease and Renal Transplantation. In Obstetric and Gynecologic Nephrology 2020 (pp. 225243). Springer, Cham. https://link.springer.com/chapter/10.1007/978-3-030-25324-0_16.

7. Sarkar M, Bramham K, Moritz MJ, Coscia L. Reproductive health in women following abdominal organ transplant. American Journal of Transplantation. 2018 May; 18 (5): 1068-1076. https://onlinelibrary.wiley.com/doi/ abs/10.1111/ajt.14697.

8. Wiles KS, Nelson-Piercy C, Bramham K. Reproductive health and pregnancy in women with chronic kidney disease. Nature Reviews Nephrology. 2018 Mar; 14 (3): 165. https://www.nature.com/articles/nrneph.2017.187. pdf? origin=ppub.

9. Serret-Montaya J, Zurita-Cruz JN, Villasís-Keever MA, Aguilar-Kitsu A, del Carmen Zepeda-Martinez C, CruzAnleu I et al. Hyperprolactinemia as a prognostic factor for menstrual disorders in female adolescents with advanced chronic kidney disease. Pediatric Nephrology. 2020 Jun; 35 (6): 1041-1049. https://link.springer.com/ article/10.1007/s00467-020-04494-7.

10. Ashuntantang GE, Garovic VD, Heilberg IP, Lightstone $L$. Kidneys and women's health: key challenges and considerations. Nature reviews Nephrology. 2018 Mar; 14 (3): 203. https://www.nature.com/articles/nrneph.2017.188.pdf?origin=ppub.

11. Chandra A, Midtvedt K, Åsberg A, Eide IA. Immunosuppression and reproductive health after kidney transplantation. Transplantation. 2019 Nov 1; 103 (11): e325-e333. https://journals.lww.com/transplantjournal/ FullText/2019/11000/Immunosuppression_and_Reproductive_Health_After.9.aspx.

12. Piotti G, Gandolfini I, Palmisano A, Maggiore U. Metabolic risk profile in kidney transplant candidates and recipients. Nephrology Dialysis Transplantation. 2019 Mar 1; 34 (3): 388-400. https://academic.oup.com/ndt/ article-abstract/34/3/388/5003174. 
13. Bonthuis M, Groothoff JW, Ariceta G, Baiko S, Battelino $N$, Bjerre $A$ et al. Growth patterns after kidney transplantation in European children over the past 25 years: an ESPN/ERA-EDTA registry study. Transplantation. 2020 Jan 1; 104 (1): 137-144. https://journals.lww. com/transplantjournal/fulltext/2020/01000/Growth_Patterns_After_Kidney_Transplantation_in.27.aspx.

14. Schmitz R, Fitch $Z \bar{W}, X u$ H, Ghali $\bar{A}$, Mehta $A K$, Guasch $A$, Kirk $A D$. Kidney transplantation using alemtuzumab, belatacept, and sirolimus: Five-year follow-up. American Journal of Transplantation. 2020 Dec; 20 (12): 3609-3619. https://onlinelibrary.wiley.com/doi/ abs/10.1111/ajt.16121.

15. Lin C-T, Liu X-N, Xu H-L, Sui H-Y. Menstrual Disturbances in Premenopausal Women with End-Stage Renal Disease: A Cross-Sectional Study. Med Princ Pract. 2016; 25: 260-265. doi: 10.1159/000444879.

16. Kudrytskaya A, Doronina O, Kalachik O. Aspects of reproductive state in women after kidney transplantation. In 22nd European Congress of Endocrinology. 2020 Aug 21 (Vol. 70). BioScientifica. https://www.endocrine-abstracts.org/ea/0070/ea0070ep403.

17. Karyalcin R, Genc V, Oztuna D, Huseynova N, Ercoz S. Gynecologic symptoms and sexual function in female kidney allograft recipients. Transplant proc. 2010 Sep; 42 (7): 2551-2555.

18. Pietrrzak B, Wielogos M, Kamniski P, Jabiry-Zieirwicz Z, Bobrowska K. Menstural cycle and sex hormone profile in kidney transplanted women. NeuroEndorinol Lett. 2006 Feb-Apr; 27 (1-2).

19. Laguerre M, Bouvier N, Guleryuz K, Doerfler A, Parienti JJ, Ait Said K, Tillou X. Sexual Dysfunction Improvement after Kidney Transplantation: A Prospective Study in Men and Women. International Journal of Sexual Health. 2020 Nov 13: 18 https:/www.tandfonline.com/ doi/abs/10.1080/19317611.2020.1842575.

20. Serret-Montaya J, Zurita-Cruz JN, Villasis-Keever MA, Aguilar-Kitsu A, del Carmen Zepeda-Martinez C, CruzAnleu I et al. Hyperprolactinemia as a prognostic factor for menstrual disorders in female adolescents with advanced chronic kidney disease. Pediatric Nephrology. 2020 Jun; 35 (6): 1041-1049. https://link.springer.com/ article/10.1007/s00467-020-04494-7.

Статья поступила в редакцию 7.08.2021 2. The article was submitted to the journal on 7.08.2021 